\title{
FORMAÇÃO EXECUTIVA EM BIM: Disciplina Plano de Execução BIM
}

Modalidade: Materiais didáticos desenvolvidos

\section{ESTRUTURA}

Figura 1: Estrutura do Plano de Execução BIM

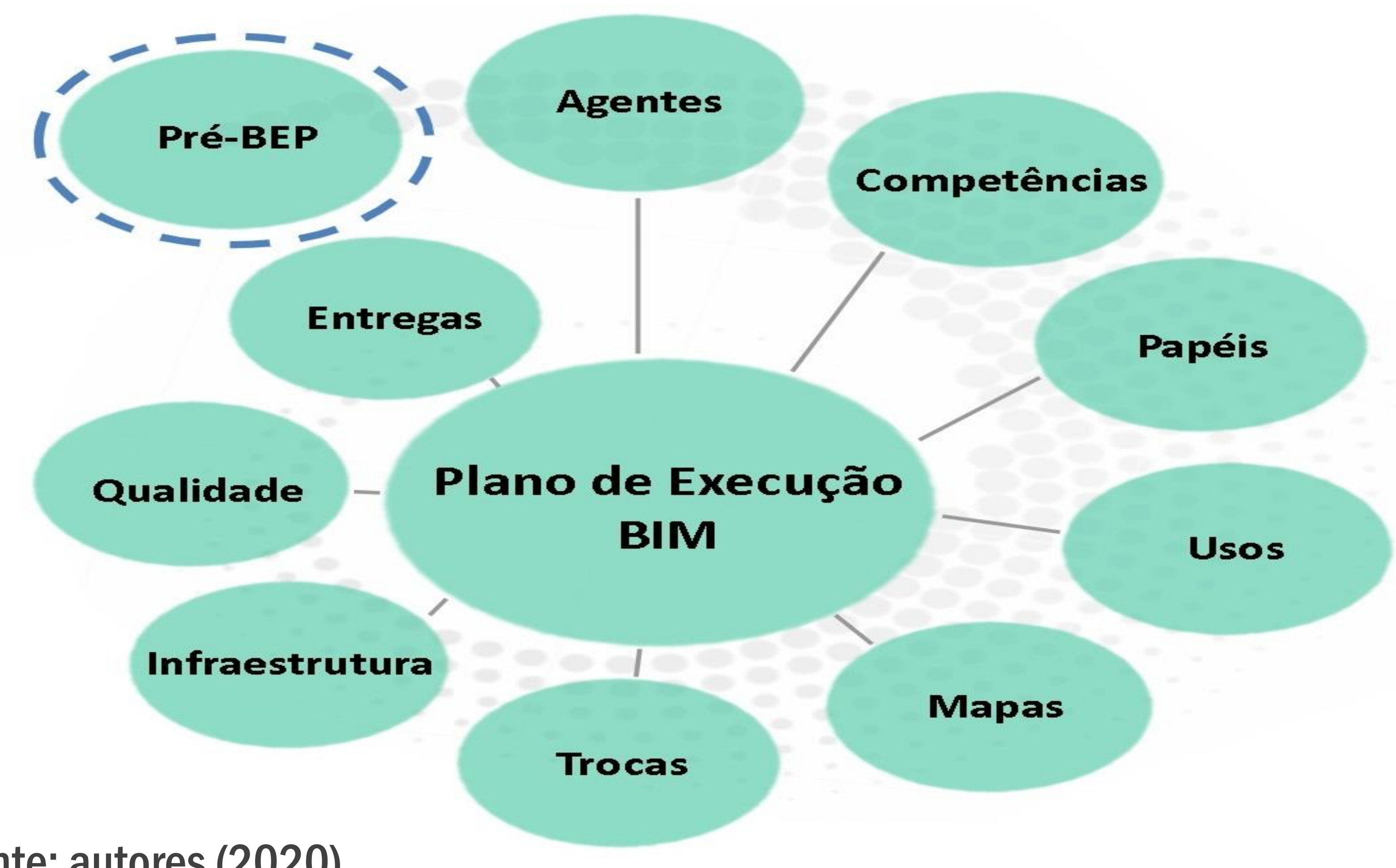

Fonte: autores (2020)

\section{ABRANGÊNCIA}

0 material didático dessa disciplina foi dividido em quatro etapas que corresponderam a quatro aulas com duração de quatro horas numa carga horária total de 16 horas. A organização da disciplina foi indexada às etapas cronológicas de um Plano de Execução BIM desde a fase de contratação dos trabalhos. Os conteúdos foram divididos de forma que cada aula teve de três a quatro etapas da estrutura de um BEP ficando a última aula reservada ao desenvolvimento de um mini BEP dentro do contexto de cada aluno.

Essa disciplina aponta os procedimentos para a execução dos projetos, desde os requisitos de informação para a contração das diversas partes envolvidas no processo até o plano de Execução BIM em si. Parte da didática das aulas se vale da participação dos alunos formando equipes que são estimuladas através de dinâmicas de discussão a resolver questões diretamente ligadas ao Plano de Execução BIM

\section{COMPETÊNCIAS DESENVOLVIDAS}

Este curso busca capacitar os alunos nas competências como: liderança, gestão de equipes, gestão da qualidade, assim como gerenciamento de projetos.

As habilidades desenvolvidas nas disciplinas foram trabalhadas em dinâmicas que seguiram uma abordagem com aplicação direta ao contexto de cada aluno.

A metodologia de ensino priorizou as atividades integradas que foram ambientadas em aplicativos de colaboração síncrona e colaborativa como Slido e Jumboard.

Figura 2: Abordagem e Metodologia de Ensino

Abordagem

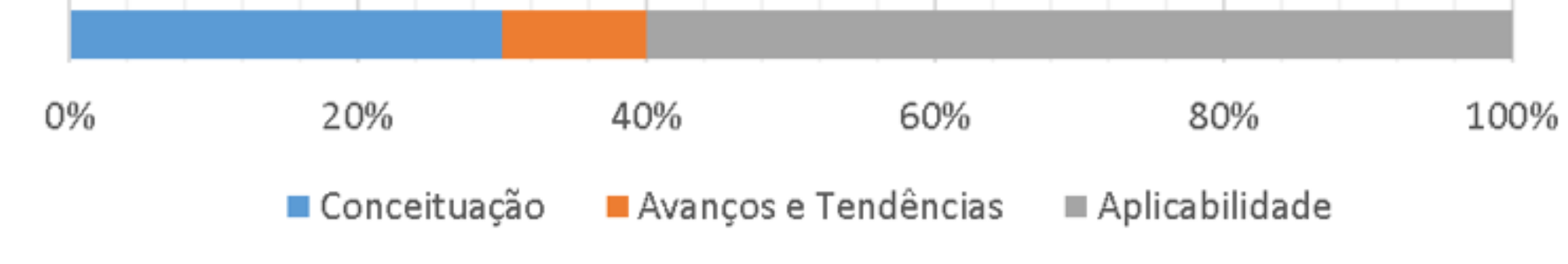

Metodologia

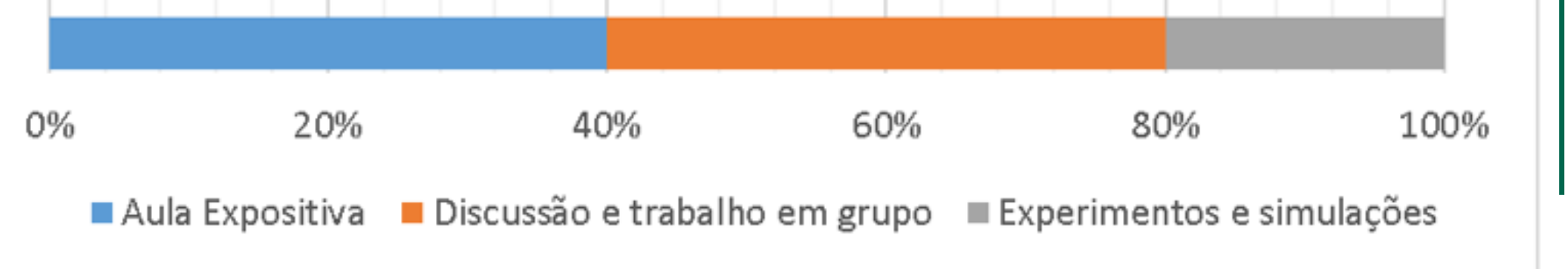

Braulio V. Cruz

Eduardo Ribeiro dos Santos

1- FGV, prof.braulio.cruz@gmail.com 2.-PRA0Q/D5/FGV,

contato@duduribeiro.com.br

\section{INTRODUÇÃO}

A indústria da construção vem exigindo que as empresas de projeto e construção utilizem no desenvolvimento de seus trabalhos os recursos oferecidos pelo BIM para projetar, executar, operar e manter 0 edifício. Diante deste cenário, começa a ter a necessidade de um planejamento para que 0 processo através do BIM aconteça de forma suave e com sucesso. A disciplina de Plano de Execução BIM, parte do curso de Formação Executiva em BIM oferecido pela Fundação Getulio Vargas (FGV) foi desenvolvida para dar suporte a profissionais que atuam no nível estratégico das organizações ligadas direta ou indiretamente à indústria da construção civil. Ela é contemporânea ao momento de esforço na tradução e adaptação da norma 19650-2. Tal norma trata da organização e digitalização de informações sobre edifícios e obras de engenharia civil, incluindo BIM, nessa parte 2 versando sobre entrega dos ativos.

\section{AGRADECIMENTOS}

À Fundação Getulio Vargas pelo apoio a realização deste trabalho.

A CAPES pelo apoio a pesquisa 